\title{
Effect of Psycho-educational Nursing Program on Body Image, Self-esteem and Quality of Sexual Life among Women with Breast Cancer
}

\author{
Zeinab Yehia Abdel-Naby Morsy ${ }^{1}$, Rania Abdel-Hamid Zaki ${ }^{2}$ and Faten Mohamed Ahmed ${ }^{3}$
}

(1) Ph.D. student of Psychiatric and Mental Health Nursing, Faculty of Nursing, Benha University, Egypt, (2) Assistant Professor of Psychiatric and Mental Health Nursing, Faculty of Nursing, Ain Shams University, Egypt and (3) Assistant Professor of Psychiatric and Mental Health Nursing, Faculty of Nursing, Benha University, Egypt

\begin{abstract}
Background: Breast cancer is one of the most serious diseases affecting physical, psychological and social health of women. Aim: This study aimed to investigate the effectiveness of psycho-educational nursing program on body image, self-esteem and quality of sexual life among women with breast cancer. Research design: A quasi-experimental design one group was utilized in this study. Setting: The study was conducted at the oncology department of Benha Health Insurance Hospital in Benha City, Qaluobia Governorate. Sample: A purposive sample was constituted the study subjects; the sample size was 40 subjects with breast cancer, which carry out (pre/post). Tools of data collection: Four tools used (1): A structured interviewing questionnaire consisting of two parts to assess socio-demographic and clinical characteristics of women with breast cancer. (2): Hopwood Body Image Scale. (3): Rosenberge Self-esteem Scale. (4): Modified WHO Quality of Sexual Life Scale. Results: There were positive highly statistical significant correlations between quality of sexual life among the studied women with breast cancer, their selfesteem and body image in pre / post program implementation. Conclusion: The psycho-educational intervention had a positive effect on improving body image, self-esteem and quality of sexual life among women with breast cancer. Recommendations: Counseling intervention program on coping strategy among women with breast cancer to improve body image, self-esteem and quality of sexual life.
\end{abstract}

Key words: Body Image, Self-esteem, Quality of Sexual Life

\section{Introduction}

Breast cancer is a pathologic process that begins with a genetic change in a single cell and can take several years to manifest. There are several treatment for breast cancer which include surgical therapy (mastectomy), radiotherapy, chemotherapy, hormonal therapy, or a combination of therapies. (Anderson et al., 2020).

Globally, breast cancer became the most common cancer, accounting for $12 \%$ of all new annual cancer cases, burden of breast cancer in women, measured by incidence, mortality, and economic costs, is substantial and on the increase. About 43,600 women in the United States are expected to die in 2021 from breast cancer. Death rates have been steady in women under 50 since 2007,but have continued to drop in women over 50.The overall death rate from breast cancer decreased by $1 \%$ per year from 2013 to 2018. These decreases are thought to be the result of treatment advances and earlier detection through screening (American Cancer Society, 2021).

Body image is defined as the mental picture of one's body, an attitude about 
physical, appearance, state of health, wholeness, normal function, and sexuality. For some individuals, a change in appearance can lead to a negative body image and various psychological problems. Negative body image among breast cancer survivors includes dissatisfaction with appearance, perceived loss of femininity and body integrity, reluctance to look at one's self naked, feeling less sexually attractive, self-consciousness about appearance, and dissatisfaction with surgical scars (Nieder et al., 2016).

Furthermore, women with breast cancer may experience changes in their physical appearance, such as loss or deformity of one or both breasts, surgical treatment scars, and skin changes related to radiotherapy. In addition, systemic treatments with chemotherapy or hormones often lead to increased body weight and hair loss. These changes are closely related to physical appearance and body image, and the obvious question is how does breast cancer and its treatment affect a woman's perception of body image? Likewise, the type of breast cancer treatment has become a primary factor in body image perception in these affected women (Fetaini et al., 2020)

Self-esteem is defined as a positive or negative attitude toward oneself based on the evaluation of one's characteristics, as well as feelings of self-satisfaction. Women's selfesteem based on their physical appearance, which has an impact on their social interactions and interpersonal relationships. It becomes even more difficult when the lady suffers from bodily changes or disfigurement as a result of an illness. Her mental attitude, body image, self-esteem, and quality of life may be negatively impacted by her perception of her physical appearance in relation to society's "ideal" (Branden, 2013).
Sexuality is complex and subjective concept that changes over times as a person ages and gains experience, it is not just the state of being physically able to perform a sex act or to conceive a child it also refers to a key characteristic of being human that includes sex, gender, sexual and gender identity, sexual orientation, eroticism, emotional attachment / love and reproduction (Den Ouden et al., 2019).

Breast cancer carries a direct threat to a women's sense of attractiveness and femininity. Responding to these changes varies with several different factors which comprise individual characteristics and aspects of their interpersonal relationships. In breast cancer, the degree of psychological response is strongly correlated to emotions about breast. Woman breast symbolizes femininity, esthetic appearance, and sexuality, feeding the baby, love and motherhood. For this reason, women usually suffer from severe psychological problems after breast cancer, such as worry about body image impairment, decreased self-esteem, and feeling of losing their femininity and reduce in sexual functions, depression, anxiety, isolation, shame and guilt, fear of recurrence and fear of death (Maleki et al., 2021).

Nurses play crucial roles in understanding and supporting the patients in their psychological, family, social, and even sexual lives after surgery as the patients need advice before and after mastectomy and accepting treatment procedures and adaptation to their new conditions. Considering the high breast cancer prevalence and mastectomy, the postsurgery consequences on psychological aspects of the patients have to be considered (Hinkle et al., 2014). 


\section{Significant of the Study}

Mastectomy produce negative effect on women's body image, self-confidence, selfesteem, emotional status, relationships and sexual life, the mastectomy patient's role in social, sexual and interpersonal situations may be altered in various ways after breast cancer surgery. A woman must learn how to deal with herself firstly to enhance and improve body image and self-esteem then learn how to deal with her family especially her husband (Amir \& Ali, 2015)

\section{Aim of the study}

The aim of this study was to evaluate the effect of psycho-educational nursing program on body image, self-esteem and quality of sexual life among women with breast cancer.

\section{Research hypothesis:}

Body image, elf-esteem and quality of sexual life will be improved after implementation of psycho-educational program

\section{Subject and Methods}

\section{Research design}

A quasi-experimental design (pre and posttest) was used to achieve the aim of the study.

\section{Research setting}

This study was conducted at the oncology outpatient clinic of Benha Insurance Hospital. Its main objective is to provide comprehensive oncology management mostly to citizens in Qalubaia governorates with all types of tumors. The structure consists of seven floors, each of which buildings departments for inpatient and outpatient services, as well as a pharmacy for medication dispensing and clinical laboratories for all patients' investigations. The majority of clinical services are covered by insurance plans

\section{Sample:}

A Purposive sample of 40 women with breast cancer who represent $10 \%$ of the total women patients (400 cases) with breast cancer of the year; 2019 -2020 based on medical records of hospital and was selected according to certain inclusion criteria and determined by using an appropriate statistical equation included in the study. The study samples were fulfilling the following

\section{Inclusion criteria}

- Willing to voluntary participate in the study.

- Women of reproductive age from18 to50 years

- At least six months after breast cancer.

- Married pre breast cancer and still married post breast

- No physical diseases affecting sexual function such as cardiovascular diseases and diabetes

- No scar or any type of lesion in the genital tract, No history of medications affecting sexual response in the woman or her husband

\section{Tools of data collection}

In order to achieve the aim of the study, the researcher used four tools to collect relevant required data, it included the following tools:-

\section{Tool (I): A Structured Interview Questionnaire:}

This tool was developed by the researcher in Arabic language and revised by supervisors to assess all related socio-demographic and clinical data of the sample including two parts as the following:-

Part 1: Socio-demographic characteristics of women such as age, level of education, occupation, residence. 


\section{Part 2: Medical history characteristics} includes clinical data of breast cancer women as duration of diagnosis, stage of the disease, treatment allergy, medications, surgery, chronic diseases and family history.

\section{Tools II: Body image scale (BIS)}

It was developed by (Hopwood, 1993) and modified by (Koleck, 2012) to measure body image in women with breast cancer. This scale consists of 10 items, Five BIS items concerned general body image issues: feeling self-conscious, dissatisfied when dressed, difficulty looking at your self-naked, avoid others because of appearance, and dissatisfied with body. The other 5 items concerned body image in relation to breast cancer experience: less physically attractive, less feminine, less sexually attractive, body less whole, and dissatisfied with scar. Scale was modified to be 16 items. The scoring systems responses being made on a Likert-type scale with options respectively as follows: (1) not at all (2) alittle (3) quit a bite (4) very much. Maximum score was (64) and minimum (16).

\section{Tool (III): Self-esteem scale}

It was a 4-point Likert developed by (Rosenberg, 1965) and modified by (Hatcher, 2009) designed to measure Selfesteem in women with breast cancer. This scale consists of ten items, five concerned with positive form and the other five concerned with negative form. Responses are made on a Likert -type scale from $1=$ not at all, to $4=$ strongly.

\section{Scoring system:}

Response were as: (4) strongly agree, (3) agree, (2) disagree, and (1) strongly disagree. The maximum score was (40) and minimum (10).

\section{Tool (IV): Quality of sexual life scale}

A modified QOSLS was used to assess the quality of sexual life in breast cancer patients.
This scale is made up of 27 questions divided into four categories: physical, psychological, social relationships, and environment.

Responses are made on a Likert -type scale from $1=$ not at all, to $4=$ strongly.

\section{Scoring system of (Developed QOSLS):}

Response were as: (5) strongly satisfied, (4) satisfied, (3) sometimes satisfied, (2) dissatisfied and (1) strongly dissatisfied. The maximum score was (135) and minimum 27). The scoring levels were arranged as follow

$$
\begin{array}{ll}
81-\geq 101 & \text { poor quality of sexual life } \\
101-\geq 115 & \text { average quality of sexual life } \\
115-\geq 135 & \text { good quality of sexual life }
\end{array}
$$

\section{Validity of the tools:}

To achieve the criteria of trust worthiness of the data collection tools in this study, tools were tested and evaluated for content validity. Content validity was tested validity by five professors (one psychiatrist, one professor in Medical Oncology, one professor in Obstetrics and Gynecology and two professors specialized in Psychiatric and Mental Health Nursing). This panel of experts approved both face, and content validity of the study tools, and its scoring systems.

\section{Reliability of the tools}

Reliability of the Arabic version of the tool was held on 40 post breast cancer women. Test-retest-reliability coefficient was held on the same patients by the same researcher within 14 days interval in the same setting. Its value for the 16 items was (0.93) which indicated that the Arabic version of BIS demonstrated excellent scale reliability.

Reliability of the tool was held on the same 40 post breast cancer women. Test-retestreliability coefficient was held on the same patients by the same researcher within 14 days interval in the same setting. Its value for 10 items was $(r=0.9)$. 
1. The reliability of the tool (quality of sexual life) that was assessed through measuring their internal consistency by determining Cronbach alpha coefficient, proved

2. to be high as indicated in the following table:

\begin{tabular}{|c|l|l|}
\hline \multirow{2}{*}{ Tools } & $\begin{array}{l}\text { No. of } \\
\text { items }\end{array}$ & $\begin{array}{l}\text { Cronbach } \\
\text { Alpha } \\
\text { Coefficien } \\
\text { t }\end{array}$ \\
\cline { 3 - 3 } & $\begin{array}{l}\text { Scale } \\
\text { reliability }\end{array}$ \\
\hline Physical domain & 10 items & 0.79 \\
\hline Psychological domain & 10 items & 0.82 \\
\hline $\begin{array}{c}\text { Social relationship } \\
\text { domain }\end{array}$ & 4 items & 0.84 \\
\hline Environmental domain & 5 items & 0.89 \\
\hline
\end{tabular}

\section{Ethical considerations:}

1. A written initial approval was obtained from the research ethical committee at the faculty of nursing, Benha University.

2. Individual oral consent was obtained from each participating breast cancer survivors after explaining the nature and benefits of the study.

\section{Pilot study}

A pilot study was conducted before embarking in the field of work on $30 \%$ (12) patients from total subjects to ascertain the clarity and applicability of the study tools. Also, it served to estimate the time needed for filling each tool. As well as to identify obstacles that might be faced during data collection. After collecting pilot study, it was found that each subject with breast cancer took 15-20 minutes to fulfill tools of the study and no modification was done and the last form was developed. So, study subjects included in the study.

\section{Field work:}

\section{A) Assessment and planning phase}

- $\quad$ Post all permissions were granted to the researcher he started Preparatory phase. Each subject was interviewed individually pre applying the planned program to collect the necessary data in privacy using all study tools, (Socio-demographic and Clinical Data Sheet, Body Image Scale, Self-esteem Scale and quality of sexual life scale .

- Researcher began data collection by introducing herself to the subjects, and explained the aim of this phase of the current study.

- Subjects were informed about their rights to withdraw from the study at any time without penalty.

- $\quad$ The Preparatory phase took a period of one month. Structured interviews conducted at the medical outpatient clinics of the Oncology. Department of Benha Health Assurance. Each interview lasted for about 15 -20 minutes.

\section{B) Implementation phase:}

The teaching sessions were conducted in class room which located in inpatient department of the Benha Insurance hospital. The classroom was air conditioned, quiet, well ventilated, well furnished, and had adequate lighting and adequate spacing for implementing expressed emotion program activities. The program content and its objectives were developed by the researcher in the form of 14 sessions each session take about 30- 90 minutes according to the breast cancer women understanding and span of attention. Sessions of expressed emotion management program focus on: 
Session 1: Introductory about program objectives and the expected outcome and describe schedule of the program.

Session 2: theoretical about the information about breast cancer

Session 3: theoretical \& practical about developing skills of solving problem and decision making

Session 4: Theoretical \& practical about (Transform negative thoughts into positive thoughts).

Session 5: Theoretical \& practical about promote self-esteem.

Session 6: Theoretical \& practical about positive self talk

Session 7: Theoretical \& practical about Positive Self Talk

Session 8: Theoretical \& practical about improving body image

Session 9: Theoretical \& practical about improving of sexual health

Session 10: practical to Developing effective communication skills with self and others

Sessions 11: practical about the management of negative feelings

Session 12: Theoretical \& practical about relaxation techniques and meditation

Session 13: Theoretical \& practical about stress management techniques.

Session 14: Summary about the program sessions and post assessment test.

\section{Statistical analysis}

The collected data were organized, analyzed using appropriate statistically significant tests. The data were collected and coded using the Computer Statistical Package for Social Science (SPSS), version 20, and was also used to do the statistical analysis of data. Data were presented using descriptive statistics in the form of frequencies and percentages. Chi-square tests were used to compare frequencies and correlation between study variables.
Degrees of significance of results were considered as follow:

- $\mathrm{p}$-value $>0.05 \quad$ Not significant (NS)

- p-value $<0.05 \quad$ Significant $(\mathrm{S})$

- p-value $<0.01$ Highly Significant (HS)

\section{Results}

Table (1): Illustrates that $70 \%$ of them haven't children. As for education $48 \%$ are secondary education. As regard to occupation $76 \%$ of the studied patients are working. Concerning residence, $60 \%$ of them live in urban areas.

Table (2): Shows that $80 \%$ of the studied subject were in the second stage of breast cancer. In addition $45 \%$ of the studied subjects are treated by chemotherapy and $72 \%$ of them have positive family history, regarding their surgical operation, it was found that $55 \%$ of them are total mastectomy.

Table (3): Denotes that, there is highly statistically significant improvement on all levels of body- image concerns among the studied subject post psycho-educational intervention

Table (4): Reveals that, there is a highly statistically significant difference of selfesteem among women with breast cancer between pre and post program implementation as regards to increased significantly after the program implementation $(\mathrm{p}<0.001)$

Table (5): Illustrates that ,the highest mean among the studied subject post program implementation increased significantly in psychological domain followed by physical domain, environmental domain and social relationship domain, and there is a highly statistically significant difference in quality of sexual life domains among women with breast cancer between pre and post program implementation $(\mathrm{p}<0.001)$. 
Table (6): Denotes that ,there is a highly statistically significant difference in quality of sexual life among the studied subjects between pre and post program implementation as regards to increased significantly after the program implementation $(\mathrm{p}<0.001)$.
Table (7): Illustrates that, there is a positive highly statistical significant correlation between quality of sexual life among the studied subject, their self- esteem and body image in Pre / Post Program Implementation $\left.\begin{array}{llll}\text { evidenced } & \text { by } \quad(\mathrm{P}< & 0.001\end{array}\right)$

Table (1): Distributions socio-demographic characteristics among the studied subjects $(\mathrm{N}=40)$

\begin{tabular}{|c|c|c|}
\hline Items & No. (40) & $\%$ \\
\hline $\begin{array}{l}\text { Age of women (years): } \\
\text { - } \quad 18-\leq 30 \\
\text { - } \quad 31-\leq 40 \\
\text { - } \quad 41-\leq 50\end{array}$ & $\begin{array}{l}6 \\
10 \\
24\end{array}$ & $\begin{array}{l}15 \\
25 \\
60\end{array}$ \\
\hline Mean $\pm \overline{\text { SD }} \quad 39.1 \pm 4.9$ & & \\
\hline $\begin{array}{l}\text { Having Children: } \\
\text { - No } \\
\text { - Yes }\end{array}$ & $\begin{array}{l}28 \\
12\end{array}$ & $\begin{array}{l}70 \\
30\end{array}$ \\
\hline $\begin{array}{ll}\text { Level of Education: } \\
\text { - } & \text { Read and write } \\
\text { - } & \text { Secondary education } \\
\text { - } & \text { High education } \\
\end{array}$ & $\begin{array}{l}13 \\
19 \\
8\end{array}$ & $\begin{array}{l}32 \\
48 \\
20\end{array}$ \\
\hline $\begin{array}{l}\text { Occupation: } \\
\text { - } \quad \text { Working } \\
\text { - } \quad \text { Not working }\end{array}$ & $\begin{array}{l}30 \\
10\end{array}$ & $\begin{array}{l}76 \\
24\end{array}$ \\
\hline \begin{tabular}{ll}
\multicolumn{2}{ll}{ Residence } \\
- Urban \\
- $\quad$ Ruler \\
\end{tabular} & $\begin{array}{l}24 \\
16\end{array}$ & $\begin{array}{l}60 \\
40\end{array}$ \\
\hline
\end{tabular}

Table (2): Distributions of clinical characteristic among the studied subjects with breast cancer $(\mathrm{N}=\mathbf{4 0})$.

\begin{tabular}{|c|c|c|}
\hline Items & No.(40) & $\%$ \\
\hline $\begin{array}{l}\text { Duration of diagnosis } \\
\text { - } \quad 6-<12 \text { month } \\
\text { - } 12->18 \text { month } \\
\text { - } \quad 18->24 \text { month }\end{array}$ & $\begin{array}{l}12 \\
20 \\
8\end{array}$ & $\begin{array}{l}30 \\
50 \\
20\end{array}$ \\
\hline Mean \pm SD $\quad 16.3 \pm 3.7$ & & \\
\hline $\begin{array}{ll}\text { Stage of breast cancer: } \\
\text { - } & \text { Stage I } \\
\text { - } & \text { Stage II } \\
\text { - } & \text { Stage III } \\
\end{array}$ & $\begin{array}{l}2 \\
32 \\
6\end{array}$ & $\begin{array}{l}5 \\
80 \\
15\end{array}$ \\
\hline $\begin{array}{l}\text { Types of Treatment } \\
-\quad \text { Chemotherapy } \\
-\quad \text { Radiotherapy } \\
\text { - Hormonal therapy } \\
\end{array}$ & $\begin{array}{l}18 \\
6 \\
16\end{array}$ & $\begin{array}{l}45 \\
15 \\
40\end{array}$ \\
\hline $\begin{array}{ll}\text { Surgical operations (Mastectomy) } \\
\text { - } & \text { Radical mastectomy } \\
\text { - } & \text { Modified radical mastectomy } \\
\text { - } & \text { Total mastectomy }\end{array}$ & $\begin{array}{l}0 \\
18 \\
22\end{array}$ & $\begin{array}{l}0 \\
45 \\
55\end{array}$ \\
\hline
\end{tabular}


Table (3): Distributions levels of body image concerns among the studied subjects pre and post implementing psycho-educational nursing program $(\mathrm{N}=40)$

\begin{tabular}{|c|c|c|c|c|}
\hline \multirow{3}{*}{$\begin{array}{l}\text { Levels of breast cancer body image } \\
\text { concerns }\end{array}$} & \multicolumn{2}{|c|}{$\begin{array}{c}\text { Psycho-educational } \\
\text { program }\end{array}$} & \multirow[t]{3}{*}{$\begin{array}{r}t- \\
\text { test }\end{array}$} & \multirow[t]{3}{*}{ P value } \\
\hline & $\begin{array}{r}\text { Pre- } \\
\text { program }\end{array}$ & $\begin{array}{r}\begin{array}{r}\text { Post- } \\
\text { program }\end{array} \\
\end{array}$ & & \\
\hline & \multicolumn{2}{|r|}{ Mean + S.D } & & \\
\hline Poor concerns of their body image & $33.31 \pm 0.1$ & $17.87 \pm 0.34$ & 22.4 & $<0.001 * *$ \\
\hline Average concerns of their body image & $\begin{array}{r}28.60 \\
\pm 11.27\end{array}$ & $\begin{array}{r}38.60 \\
\pm 11.27\end{array}$ & 25.8 & $<0.001 * *$ \\
\hline Good concerns of their body image & $34.25 \pm 4.77$ & $44.25 \pm 4.77$ & 29.8 & $<0.001 * *$ \\
\hline
\end{tabular}

Highly significant difference $\mathrm{p}<0.001$

Table (4): Levels of self-esteem to breast cancer women pre and post implementing psycho-educational program $(\mathrm{N}=40)$

\begin{tabular}{|c|c|c|c|c|c|c|}
\hline \multirow[t]{3}{*}{$\begin{array}{c}\text { Levels of self-esteem to breast cancer } \\
\text { women }\end{array}$} & \multicolumn{4}{|c|}{$\begin{array}{r}\text { Psycho-educational } \\
\text { program }\end{array}$} & \multirow[t]{3}{*}{$\mathbf{X}$} & \multirow[t]{3}{*}{ P value } \\
\hline & \multicolumn{2}{|c|}{$\begin{array}{r}\text { Pre } \\
\text { program } \\
\end{array}$} & \multicolumn{2}{|c|}{$\begin{array}{r}\text { Post } \\
\text { program } \\
\end{array}$} & & \\
\hline & No. & $\%$ & No. & $\%$ & & \\
\hline Poor concerns of their self-esteem & 18 & 45 & 3 & 7.5 & 22.5 & $<0.001 * *$ \\
\hline Average concerns of their self-esteem & 10 & 25 & 12 & 30 & 27.4 & $<0.001 * *$ \\
\hline Good concerns of their self-esteem & 12 & 30 & 25 & 62.5 & 26.2 & $<<0.001 * *$ \\
\hline
\end{tabular}

Highly significant difference $p<0.001$

Table (5): Comparison between total mean scores of quality of sexual life domains among the studied subjects pre / post implementing psycho-educational program $(\mathrm{N}=40)$.

\begin{tabular}{|c|c|c|c|c|}
\hline \multirow[t]{3}{*}{ quality of sexual life domains } & \multicolumn{2}{|c|}{$\begin{array}{l}\text { Psycho-educational } \\
\text { program }\end{array}$} & \multirow[t]{3}{*}{ t- test } & \multirow[t]{3}{*}{ P value } \\
\hline & $\begin{array}{l}\text { Pre- } \\
\text { program }\end{array}$ & $\begin{array}{l}\text { Post- } \\
\text { program }\end{array}$ & & \\
\hline & Mean + S.D & Mean + S.D & & \\
\hline Physical domain & $30.4 \pm 6.2$ & $35.22 \pm 6.9$ & 23.5 & $0.001 * *$ \\
\hline psychological domain & $28.14 \pm 6.32$ & $39.27 \pm 7.2$ & 25.8 & $0.001 * *$ \\
\hline social relationship domain & $29.44 \pm 4.92$ & $31.17 \pm 6.54$ & 20.7 & $0.001 * *$ \\
\hline Environmental domain & $28.81 \pm 4.76$ & $32.54 \pm 6.23$ & 22.3 & $0.001 * *$ \\
\hline
\end{tabular}

Highly significant difference $p<0.00$ 
Table (6): Relation between demographic characteristics of women with breast cancer and their body image Pre and Post Program Implementation (N=40).

\begin{tabular}{|c|c|c|c|c|}
\hline \multirow[t]{3}{*}{$\begin{array}{l}\text { Levels of quality of sexual } \\
\text { life }\end{array}$} & \multicolumn{2}{|c|}{$\begin{array}{c}\text { Psycho-educational } \\
\text { program }\end{array}$} & \multirow{3}{*}{ t- test } & \multirow{3}{*}{$P$ value } \\
\hline & $\begin{array}{r}\text { Pre- } \\
\text { program }\end{array}$ & $\begin{array}{r}\text { Post- } \\
\text { program }\end{array}$ & & \\
\hline & \multicolumn{2}{|r|}{ Mean \pm S.D } & & \\
\hline $\begin{array}{ll}\text { Poor quality of sexual } \\
\text { life }\end{array}$ & $40.8 \pm 0.9$ & $19.99 \pm 0.9$ & 15.8 & $<0.001 * *$ \\
\hline $\begin{array}{l}\text { Average quality of sexual } \\
\text { life }\end{array}$ & $28.63 \pm 2.45$ & $17.33 \pm 4.2$ & 12.9 & $<<0.001 * *$ \\
\hline $\begin{array}{l}\text { Good quality of sexual } \\
\text { life }\end{array}$ & $15.34 \pm 4.22$ & $31.67 \pm 7.15$ & $\overline{17.4}$ & $<0.001 * *$ \\
\hline
\end{tabular}

Highly significant difference $p<0.001$

Table (7): Correlation between quality of sexual life, self-esteem and body image among the studied subjects in Pre / Post Program Implementation (N=40).

\begin{tabular}{|l|l|l|l||l||}
\hline \multirow{2}{*}{ Items } & \multicolumn{2}{|l||}{ Total quality of sexual life } & $\begin{array}{l}\text { P- } \\
\text { value }\end{array}$ \\
\cline { 2 - 4 } & $\begin{array}{l}\text { Pre } \\
\text { program }\end{array}$ & $\begin{array}{l}\text { P- } \\
\text { value }\end{array}$ & $\begin{array}{l}\text { Post- } \\
\text { program }\end{array}$ & \\
\hline \hline & & 0.05 & & \\
Total self esteem & $\mathrm{r}=.153$ & $\mathrm{~S}$ & $\mathrm{r}=.361$ & 0.001 \\
\hline & & 0.05 & $\mathrm{H} . \mathrm{S}$ \\
Total body image & $\mathrm{r}=.187$ & $\mathrm{~S}$ & $\mathrm{r}=.245$ & 0.001 \\
H.S
\end{tabular}

Statistically significant difference $P<0.05$

\section{Discussion}

Breast cancer has a profound impact on a woman's physical image, self-esteem, emotional well-being, relationship, and sexual life. Breast cancer women's roles in social, sexual, and interpersonal situations can be altered in a variety of ways, particularly after mastectomy, which can lead to feelings of inadequacy or weakness, poor body image, loss of attractiveness, and sexual dysfunction in the affected women, which can lead to mood disorders (Hamed et al., 2015).
Therefore, the current study aimed to evaluate the effect of psycho-educational nursing program on body image, self-esteem and quality of sexual life among subjects with breast cancer at outpatient clinic of Benha Insurance Hospital.

Results of the current study revealed features describing the selected studied sample. In the current study, the socio-demographic characteristics of subjects showed number of interesting features in relation to age, having children, education, residence and occupation. 
As for age, the results of the present study revealed that that three fifth of the studied subjects are in age ranged between $(41-\leq 50)$ years and only $15 \%$ of them in age ranged (18 $-\leq 30$ ) years with a mean age of $39.1 \pm 4.9$.

These results indicate that women by reaching the age of maturation and productivity constitute the largest portion of affected population. In addition mastectomy at the age of 40 to 50 years old cause further shock for those women who come close to the maturational crisis of menopausal phase and start to suffer number of threats to their sexuality and femininity leading to the development of several psychological disorders only to mention depression, despair, fear, anxiety, anger and resentment. Prevalence of this age group has been found congruent with other studies in Egypt and different countries. For instance, in Egypt, Hamd et al., (2019) reported that the most common age of mastectomy is $(40-<50)$ years old. Similarly in Iran Faghani \& Ghaffari, (2016) reported that the most common age Participants' mean age was $43.2 \pm 4.6$ years, and aged from (35-<45).

In relation to have children the result showed that more than two third of them haven't children; it could be due to hormones which produced during the ovulation cycle can stimulate cell growth, which can help cancerous cells multiply. But subjects who have been pregnant and breast fed have fewer periods, and therefore produce fewer cancerinducing hormones. That may be why lifetime breast cancer risk generally declines with every child a woman has. These findings were congruent with Hamad et al., (2015) who reported that that more than three fifth of studied subjects with breast cancer haven't children and according to American cancer society, (2021) mentioned that most of researches worldwide found that there were significance relation between having child, breast feeding and breast cancer. Conversely Maleki et al., (2021) who reported that more than two third of the studied subjects with breast cancer had 1-2 children.

Concerning to the educational level the results revealed that the majority of the studied subjects educational level were half were secondary level of education, one third of the studied subjects were read and write and only less than one quarter were highly educated .These findings of the educational level of the current studied subjects showed that about two third of the sample achieved reasonable levels of education, that facilitated easy understanding, acceptance and interaction with the psycho-educational intervention program, this was reflected immediately post intervention. As they had an insisting desire to gain knowledge and learn how to cope with their problems

From the researcher's point of view and according to the characteristics that were identified when choosing the studied sample, the sample should be able to read and write to make them able to participate, comprehend and understand when applying psycho-educational program

In addition, most of the subjects who visit the Health Insurance Hospital in Benha are employees of various companies and institutions that refer them to receive treatment services. These findings as regard to education are congruent with Faghani \&Ghaffari (2016) who reported that less than half of the studied subject with breast cancer subjects were diploma, less than one quarter were highly educated and only of them can read and write. Conversely Maleki et al., (2021) who reported that Majority of the subjects had an under diploma education level (42.9\%). 
As regard to occupation more than three quarter $(76 \%)$ of the studied breast cancer subjects were working. From the researcher point of view working subjects exposed to different types of environmental, physical and emotional changing according to occupational category, work activities, work shift patterns, and exposures to chemical and physical agents may vary notably in medical jobs. This means that the multiple exposures encountered in any occupation could act in concert to lead to an elevated risk for breast and other cancers. In addition to nutritional life style of working subjects may effect on general health status because of preferred take away and refrigerated food. This study agreed with Mohamed et al., (2017), who reported that about two thirds of the post mastectomy subjects were working, while more than one third of them were house-wives. In contrast Maleki et al., (2021), (Hamed et al., (2015) \& Faghani \&Ghaffari (2016) who reported that about two third of the studied women with breast cancer were housewives.

Concerning residence, the result showed that more than half of the studied subjects with breast cancer live in urban areas. From researcher point of view that the selected sample from Benha health Insurance Hospital were employed and live near place of their work . This study was consistent with (Maleki et al., (2021) who reported that about two third of the studied subjects with breast cancer were live in urban areas and less half of them were live in rural area. In contrast Hamed et al., (2019) who reported that more than half of the studied subjects were lived in rural areas and less than half of the studied subjects were lived in urban areas.

According to clinical characteristics of the studied subjects with breast cancer. The results showed that, half of them have their diagnosis since 12 to 18 months. From the researcher point of view after one year from diagnosis of breast cancer subjects start thinking about their body image, self-esteem and sexual activity so they search to solve their problems in order to deal with her children, husband and surrounding people. In contrast immediately after diagnosis of breast cancer they were shocked, and may provoke psychological challenges such as depression, anger, uncertainty about the future, hopelessness, fear of recurrence of cancer, fear of separation from relatives, fear of pain, low self-esteem, body image impairment, anxiety of not being loved or shown interest, and fear of death and they refuse any advice and education.Also from researcher opinion that breast cancer subjects who diagnosed 2-5years ago were coped with their disease .This study is agree with Faghani \& Ghaffari (2016) who select all sample size over 1 year from diagnosis of breast cancer. In contrast Hamed et al., (2019) who select their sample size from (1-5) years from diagnosis of breast cancer

According to the stage of breast cancer the result found that more than three quarters of the studied subjects were in $2^{\text {nd }}$ stage of breast cancer. In addition to less half of them were treated by chemotherapy and about three quarter of them had positive family history, regarding their surgical operation, the result also found that more than half of the studied subjects were total mastectomy. This study agrees with (Maleki et al., (2021) who reported that most participants were at early stage (II), had total mastectomy and had family history.

The result revealed that there were more than two third of a psychological complains among the studied subjects with breast cancer. This complains included psychological distress such as depression, anhedonia, hopelessness 


\section{Zeinab Yehia Abdel-Naby, Rania Abdel-Hamid Zaki and Faten Mohamed Ahmed}

and anxiety. In another hand less than one third of the studied subjects with breast cancer weren't suffer from any psychological problems. It could be due to misleading as these subjects might be using denial or reaction formation as defense mechanisms to appear accepting their body appearance and avoiding negative feelings related to disfigurement in their body image. Evidence of this notion is found in Akel, et al., (2017) who stated that half of the studied subjects with breast cancer show depressive and anxiety symptoms in the first year after diagnosis and treatment, and this had a major impact on subjects' lives.

In addition Hamed et al., (2019) who stated that depression may be present with feelings of guilt, worthlessness, hopelessness, lowered self-esteem, social withdrawal or suicidal preoccupation.. Furthermore, Chang, et al., (2019) who found that depression in subjects who underwent mastectomy surgery derives from several aspects, the first and most important is the change in body structure. Breast removal is equivalent to the loss of femininity and shapes the sense of inferiority, prompts the feeling of embarrassment, isolation from society and even isolation from family un fortunately, this would result in increased distance between the patient and her partner.

The result also revealed that about three quarter of the studied subjects with breast cancer had a sexual complains such as pain during intercourse, dryness of the vagina, and lack of tired after sex, lack of desire for sexual life it could be due to diagnosis and treatment of breast cancer as chemotherapy, radiotherapy and hormonal therapy that affect not only physically but also effect on quality of sexual life as hormonal disturbances may cause lack of desire and lack concentration during sex due to anxiety so subjects with breast cancer were preoccupied with breast cancer complication and their body image

This result agree with Yan et al., (2019) reported that more than three quarter of the studied subjects with breast cancer had a sexual complains. Also Hamed et al., (2015) reported that more than two third of the studies subjects had complains of sexual dysfunction in all ages. And also Chang, et al., (2019) reported that the sexual dysfunctions often observed in subjects with breast cancer include the loss of libido, Dyspareunia, vaginal atrophy and dryness, reduced breast sensitivity and reduced sexual pleasure.

According to the hypothesis of the current study: Implementation of "Psycho-educational nursing program" on subjects with breast cancer will improve their body image, selfesteem and quality of sexual life. The present study findings that reflected by tables and figures indicated that the differences between pre and post program test scores of the studied subjects were significant and support the study hypothesis

Breast cancer treatment had an effect on body image due to surgery scars, weight loss or gain, skin changes, hair loss or regrowth can change the way you feel about your body. Some subjects develop lymphedema (swelling) after surgery or radiotherapy to lymph nodes in the armpit Boing et al., 2020) .So researcher apply psycho educational nursing program to improve and enhance breast cancer subjects body image after using modified Hopwood body image scale (HBIS) to assess body image pre and post implementing program.

In this respect the results denoted that there were highly statistically significant $(p$ $<0.001)$ difference in all items of body image subscale between pre and post implementing psycho-educational nursing program. 


\section{Effect of Psycho-educational Nursing Program on Body Image, Self-esteem and Quality of Sexual Life among Women with Breast Cancer}

It could be due to explain in the light that, participation in group discussion, teaching subjects to transform negative thoughts about their bodies into positive thoughts would have improved their negative perception of their bodies as well as increasing their self-esteem and self-confidence. Improved self-esteem and self-confidence would improve their adaptation to the actual/altered body image disturbance and reduce the negative feelings of stigma and loss of breast.

This result was in agree with Hamed et al., (2019) who reported that there was significant improvement in body image concerns as there was a decrease in the mean score of post mastectomy subjects's concerns after receiving the psycho educational program. Statistically significant differences were also found between different levels of body image concerns before and after the program.

In contrast Andreis, (2018) found that there was no significant effect on body image after psycho- educational program for subjects with mastectomy mentioned that subjects after mastectomy had major differences regarding to body image in the first year after the surgical procedure, but this difference decreases over time. However, it was also reported that a considerable number $(91 \%)$ of subjects had persistent negative body image over three years and subjects need more time to cope with cancer and its treatment.

Regarding to effect of the intervention program on self -esteem among breast cancer subjects. The current study results revealed that there were a highly statistically significant difference between levels of self-esteem before and after applying the psycho educational nursing program and there were a statistically significant increase in the mean score of self- esteem of the studied subjects after the psycho educational program. This result indicates that the program was successful in improving post mastectomy subjects self- esteem. This could related to the structure and the content of the program which combined both scientific knowledge about the disease, its treatment, and development of soft skills of communication and problem solving techniques, as well as enhancing the selfdisclosure capabilities. This program worked on supporting these subjects in understanding and accepting their illness, improving their ability to make proper decisions so that they will be able to effectively manage their problems. These factors could have led to the observed significant improvement in their selfesteem.

Moreover, teaching subjects how to use positive thinking rather than negative one did help them to face their problems in a realistic manner based on problem solving rather than useless emotional reactions. Application of the program entailed self-disclosure, discussion of their problems in a comfortable manner, positively talk about self-worthiness these all could have helped the recorded improvement in their self-esteem and self-confidence and the decrease their negative feeling about their body image after mastectomy. The program also worked on training these subjects on selfcontrol of negative emotions associated with mastectomy to improve their self-esteem. To promote after program improvement subject subjects were provided with a simplified booklet that include necessary information about cancer breast, self-examination and recommended treatment modes/ centers as well as future perspectives for breast reconstructing plastic surgery.

These results are similar to Daneshvar et al., (2020) who found that breast cancer 
subjects had higher self-esteem after psycho educational intervention. On the same line Richard et al., (2019) stated that self-esteem improved after group educational sessions through combining written information with lectures, including guidebooks and printed educational materials and this help people feel more confident to raise their concerns and discuss their symptoms.

This finding is harmonious with Faghani \&Ghaffari (2016) who reported that a psychoeducational program caused positive changes in levels of quality of sexual life in women with breast cancer. In contrast Cara et al., (2017) who stated that the educational program had no effect on the physical symptoms associated with the sexual life of women diagnosed with breast cancer, such as pain during sexual activity, vaginal adhesions, dryness, lack of desire for sex, and lack of orgasm, because women are ashamed of frankness with the medical team and do not speak about sexuality.

These results also illustrated the psychological aspect of the quality of sexual life among breast cancer women. It showed that the percentage of women subject to the study who are afraid to ask for sex from their husbands and feel embarrassed to receive guidance for life decreased from $(76 \%$ and $77 \%)$ to $(4 \%$ and $10 \%)$ respectively after implementing the psycho-educational program.

It could be due to Egyptian cultural considerations, heavenly religions, customs and traditions that make women unable to talk about the sexual life that links between them and their husbands, in the period before implementing the educational program, but after the application, and women have become able to express their feelings and towards their husbands interpreted the success of the program and the researcher's ability to create an atmosphere of affection and intimacy among the studied sample.

It was noticed during the study in the health insurance of Benha hospitals unit under the Egyptian Ministry of Health that they did not reach the optimum level of quality and performance to help solve the sexual problems of couples with chronic diseases and cancer. For example, no counseling or training is provided regarding how to treat sexual problems during breast cancer. Therefore, women with breast cancer have no awareness of the quality of sexual life after breast cancer and often rely on unreliable sexual health information suggested by others and that they know from each other while chatting and talking during waiting periods.

This result is consistent with Yan et al., (2020) who stated that Effective patient-doctor communication about sexuality could correct the misguided sexual attitudes about cancer

\section{Conclusion}

There was significant improvement in body image, self-esteem and quality of sexual life among women with breast cancer after implementing psycho-educational program than before. In addition to there was a highly statistically significant association between scores of body image, self-esteem, and quality of sexual life among the studied women with breast cancer. According research hypothesis the findings of the present study found that the psycho-educational nursing program has a positive effect on improving body image, selfesteem and quality of sexual life among women with breast cancer.

\section{Recommendations}

- Implementing psycho-educational training program for health care professional nurses about how to improve body image, selfesteem and quality of sexual life. 
- Counseling intervention program on coping strategy among women with breast cancer.

- Psychosocial nursing intervention program on psychological problems among women with breast cancer.

- Educational program should be presented to guide family care givers of women with breast cancer about how to deal with the patients.

- Further studies should be done on along numbers of women with breast cancer to teach them how to improve their body image, self-esteem and quality of sexual life.

- Additional research in liaison psychiatric nursing is needed, especially in areas of chronic diseases, and quality of sexual life.

- Duplication of the study using a large sample in different correctional setting to generalize the results.

- A training program must be prepared and submitted to the Egyptian Ministry of Health to enforce Psychiatric Liaison Nursing Consultation in these hospitals to conduct structured training program through a periodical workshops for all nurses especially nurses dealing with cancer patients focusing on knowledge regarding quality of sexual life.

\section{References}

Akel, R., El Darsa, H., Anouti, B., Mukherji, D., Temraz, S., Raslan, R., Tfayli, A \& Assi, H. (2017). Anxiety, depression and quality of life in breast cancer patients in the levant. Asian Pac. J. Cancer Prev., 18, 2809.

American Cancer Society. (2021): Cancer Facts \& Figures Available at: https://www.cancer.org/content/dam/cancerorg/research/cancer-facts-and-statistics/annualcancer-facts-and-figures/2021/cancer-factsand-figures-2021.pdf.
Amir M \& Ali Z., (2015). Quality Of Life And Related Factors Among The Women Undergoing Mastectomy, Iran J Nurs Midwifery Res. 20(2): 287-291.

Anderson , BO., Duggan ,C., Adebamowo , C \& Agarwal G, Ali, Z., (2020): Breast cancer treatment: A phased approach to implementation. Cancer., 126 Suppl 10: 236578. http://www.ncbi.nlm.nih.gov/pubmed/ 3234857

Andreis, F. (2018). Impact of a PsychoEducational Team in early Breast Cancer Patients' Coping Strategies: The Venere Project. Rev Recent Clin Trials, 13(4):274280.

Boing, L., do Bem , T., Vieira, M., Pereira, G., Moratelli, J., Sperandio, F., Bergmann, A., Dias, M.\& Guimarães, A.,2020). Pilates and dance to patients with breast cancer undergoing treatment: Study protocol for a randomized clinical trial-MoveMama study. Trials, 21, 35. [CrossRef].

Branden, N. (2013). What self-esteem is and is not. Retrieved fromhttp://www.nathanielb randen.com/what-self-esteem-is-and-is-not.

Cara ,S., Shari ,G., Raymond, E., Baser., Deborah ,J., Gold frank., Nadeem R. AbuRustum \& Richard ,R., (2017). Sexual health needs and educational intervention preferences for women with cancer .

Chang ,Y., Chang, S \& Chiu ,S., (2019). Sexual problems of patients with breast cancer after treatment: a systematic review. Cancer Nurs. ;42(5):418-425. doi: 11097/NCC. 0000000000000592 .

Daneshvar, M., Vakilian, K., ZadehEmran, A. \& Zadeh, R. (2020). The Effect of ACT on Self-Esteem and Self-efficacy of Women with Breast Cancer in Iran. Curr. Wom. Health Rev., 16, 74-80. 
Den Ouden ,M., Keurhorst, M., Uitdehaag, J\& Vocht M., (2019). Intimacy and sexuality in women with breast cancer: professional guidance needed. Breast Cancer.;26(3):32632.

Faghani ,S \& Ghaffari ,F., (2016). Effects of sexual rehabilitation using the PLISSIT model on quality of sexual life and sexual functioning in post-mastectomy breast cancer survivors. Asian Pac J Cancer Prev. ;17(11):4845.10.22034/APJCP.17.11.484 5 [PMC free article] [PubMed].

Fetaini, M., Hawari, A., Kaki, F., Ujaimi, R., Tashkandi, H\&AbuSanad, A. (2020). Impact of breast cancer treatments on body image and quality of life in survivors. IJMDCs , 4, 635-644.

Hamed, S., El-Etreby, R ., Mahgoub,N., ElBoraie,O \& Esmail,M., (2019). Impact of Psycho-educational Program on Body Image Concerns and Mental Adjustment among Post Mastectomy Women. International DOI:https://doi.org/10.15520/ijnd.v9i01.2423

Hamed, S., El-Etreby,R ., Mahgoub,N., ElBoraie,O \& Esmail,M., (2015) . Quality Of Sexual Life Among Postmastectomy Women, Mansoura Nursing Journal (MNJ) vol.2 No.2 ISSN:18235-2015

Hatcher, J., (2009). Psychometric properties of the Rosenberg self-esteem scale in African American single mothers. Issues Ment Health Nurs. Feb;30(2):70-7. doi: 10.1080/01612840802595113. PMID: 19212864.

Hinkle, J., Cheever, K., Brunner, M \& Suddarth, S., (2014).Textbook of MedicalSurgical Nursing. 13th ed. Philadelphia: Wolters Kluwer Health | Lippincott Williams \& Wilkins;. 303-316 p.
Hopwood, P., (1993). ABody Image Scale for use with cancer patient.European Journal of Cancer , 37, 189-197.

Koleck, M., (2012). The Body-Image Questionnaire: an extension. Perceptual and Motor Skills, 94, 189-196.

Maleki, M., Mardani, A., Ghafourifard, M.,\& Vaismorad,m.,(2021). Qualitative exploration of sexual life among breast cancer survivors at reproductive age. BMC Women's Health 21, 56 (2021).

Mohamed, Sh., Abd El Halim , Z., Ibrahim ,M \& Mohamed M ., (2017). The Effect of Psycho Educational Nursing Program on Coping and Quality of Life of Patients Undergoing Chemotherapy, Egyptian, Journal of Health Care, 2017 EJHC Vol.8 No.3

Nieder, S., Becker, I \& Cerwenka, M., (2016). Body Image In Young Gender Dysphoric Adults: A European Multi-Center Study Arch Sex Behav, 45 Pp. 559-574

Richard, A., Harbeck, N., Wuerstlein, R \& Wilhelm, F., (2019). Effects of a beauty care intervention on depressive symptoms, quality of life, and self-esteem in patients with early breast cancer. Psychooncology, 28, 401-407. [CrossRef.

Rosenberg, M., (1965). Rosenberg self-esteem scale (RSE).Acceptance and commitment therapy. Meas. Package , 61, 18.80 .

Yan, J., Tanimoto, T., Ozaki, A., Lu, X., Che, B., Zhang, Y., Chen, P \& Wang, J., (2019). The relationship between sexual activity and sexual attitudes among breast cancer survivors in China. Cancer medicine, 9 (10), 3425-3436. 
تأثير برنامج التمريض النفسي التعليمي على صورة الجسم وتقدير الأت ونوعية الحياة الجنسية بين النساء المصابات بسرطان الثدي

$$
\text { زينب يحيى عبدالنبي - رانيا عبدالحميد ذكي - فاتن ححم احمد }
$$

يعتبر سرطان الثدي من أحدي الامر اض الخطيرة التي تؤثر جسديا ونفسيا وإجتماعيا علي صحة النساء ـ لللك تواجه النساء المصابات بسرطان الثذي واللاتي تخضعن لأنواع مختلفة من العلاج خاصة استثئصال الثدي مشاكل تؤثر على صورة أجسادهن واحتر امهن لذاتهن ونوعية حياتهن الجنسية. لذا هدفت هذه الدراسة إلى تقييم تأثير البرنامج النفسي التعليمي علي صورة الجسد وتقدير الذات ونوعية الحياة الجنسية بين النساء المصابات بسرطان الثذي والتي تلجا لعمليات الاستئصال وقد أجريت هذه الدراسة علي ·ـ سيدة مصابة بسرطان الثذي وتم استصاله نتيجة الورم واللاتي حضرن بقسم الأور ام مستشفى بنها للتأمين الصحي بمدينة بنها بمحافظة القليوبية. وقد وضحت نتائج الدراسة وجود علاقة اليجابية ذات دلالة إحصائية عالية بين نوعية الحياة الجنسية لدى النساء المدروسات المصابات بسرطان الثذي وتقدير هن لذاتهن وصورة أجسادهن في مرحلة ما قبل وما بعد تتفيذ البرنامج النفسي التعليمي ـ. كما اوضحت أيضا ان تطبيق البرنامج النفسي التعليمي له أثر إيجابي في تحسين صورة الجسم ، وتقدير الذات ونوعية الحياة الجنسية بين النساء المصابات بسرطان الثذي.و أوصت الدراسة بضرورة عمل برنامج تدخلي ارشادي حول إستراتيجية التكيف والتأقلم مع المرض بين النساء المصابات بسرطان الثذي لتحسين صورة الجسم وتقدير الذات ونوعية الحياة الجنسية. وأوصت أيضا بضرورة ازدو اجية الدراسة باستخدام عينة كبيرة في بيئة تصحيحية مختلفة لتعميم النتائج. 